Article

\title{
Improving the E-Commerce Business Model in a Sustainable Environment
}

\author{
Mingwei Sun ${ }^{1}$, Katarzyna Grondys ${ }^{2, *} \mathbb{C}$, Nazim Hajiyev ${ }^{3}$ and Pavel Zhukov ${ }^{4}$ \\ 1 College of Computer Science and Technology, Tonghua Normal University, Tonghua 134000, China; \\ sunmingwei7@163.com \\ 2 Faculty Management, Czestochowa University of Technology (CUT), 42-201 Czestochowa, Poland \\ 3 Department of Economics and Business Administration, Azerbaijan State University of Economics (UNEC), \\ Baku 1001, Azerbaijan; n.hajiyev@unec.edu.az \\ 4 Department of Public Finance, Financial University under the Government of the Russian Federation, \\ 117437 Moscow, Russia; Paul-joukov@yandex.ru \\ * Correspondence: katarzyna.grondys@pcz.pl
}

Citation: Sun, M.; Grondys, K.; Hajiyev, N.; Zhukov, P. Improving the E-Commerce Business Model in a Sustainable Environment. Sustainability 2021, 13, 12667. https:/ / doi.org/10.3390/su132212667

Academic Editor: Adnan ul Haque

Received: 13 October 2021

Accepted: 11 November 2021

Published: 16 November 2021

Publisher's Note: MDPI stays neutral with regard to jurisdictional claims in published maps and institutional affiliations.

Copyright: (c) 2021 by the authors. Licensee MDPI, Basel, Switzerland. This article is an open access article distributed under the terms and conditions of the Creative Commons Attribution (CC BY) license (https:// creativecommons.org/licenses/by/ $4.0 /)$.

\begin{abstract}
The purpose of this study is to develop a comprehensive methodological approach to assess the sustainability of the e-commerce business model based on the integration of key performance indicators into a single vector of business model sustainability. The proposed vector approach allows for predicting and evaluating the effects of different kinds of measures, identifying and implementing the most effective tools for sustainable e-commerce business development. The methodology of this study is based on correlation, cluster and regression analysis. The scientific contribution of this study is the proposed methodological approach, which not only allows one to analyze business model sustainability, but also to compare companies in a competitive environment to determine the priorities of their functioning to achieve leadership positions on the background of sustainable development. The correlation analysis proved that in modern conditions, both economic and environmental components are significant for business model effectiveness in e-commerce. The clustering of the studied e-commerce companies provided an opportunity to take into account the peculiarities of the studied companies, to group them by similar performance indicators. This made it possible to develop more accurate regression models for each cluster. In this case, there is a correlation between the sustainability vector of the business model of a company and its assignment to a particular cluster. The conducted modeling and determination of the level of business model sustainability allowed for determining a relationship between it and the performance of e-commerce companies in the context of economic, environmental and social dimensions. At the same time, the results show that increasing the sustainability vector brings a company closer to the business sustainability benchmark.
\end{abstract}

Keywords: business model; clustering; correlation; e-commerce; regression; sustainability

\section{Introduction}

The pace and scale of technological change over the past decade has led to a revolution in business, including retail. Around the world, there has been intense growth in the ecommerce market (retail sales that are conducted through electronic channels). The World Economic Forum predicts that this trend will continue and that in 2026 online commerce will account on average for more than $40 \%$ of all retail sales [1]. E-commerce can be seen as a natural consequence of information society development, although classical theories of information society do not directly refer to this phenomenon. In modern conditions, Information and Communications Technology (ICT) is among the most important production resources and is the basis for e-commerce functioning as well as a significant factor of socio-economic development. E-commerce is a qualitatively new formation, provides a multifunctional service society and is a means to meet the needs of consumers [2]. E-traders 
must use information from multiple sources to guide and drive consumer decision-making by combining user buying habits using a cell phone. They can implement accurate recommendations by researching user demand, consumer behavior and consumer preferences [3]. It is necessary to consider what functions and standards online stores will need to meet in order to succeed and adapt to the changing preferences and requirements of a buyer and their perception of the environment through the lens of, for example, sustainability [4].

At the same time, there is a worldwide desire today to address issues that are related to the sustainable development concept. In society, many businesses are making efforts to operate in accordance with the requirements of this concept, which has gained great popularity worldwide and in the field of e-commerce. In addition, the sustainability principle has become widespread among consumers, who also pay special attention to the activities of companies in this direction. In this regard, sustainability is seen as an effective tool to ensure competitiveness and achieve success in the struggle to increase the audience of consumers in virtual markets [5].

The active development of e-business implies its contribution to the sustainability of companies. Thus, they have a duty to preserve the environment, prevent it from being destroyed and ensure that the world as a whole is preserved. This study specifies the elements and interconnections of the e-commerce ecosystem in the context of sustainable development. The supersystem is the electronic economy, which determines the environment of the electronic market. Measuring and studying the ecosystem through the prism of the e-commerce business model are impossible without a defining integral indicator due to the great complexity of the system. Therefore, to measure business model effectiveness in e-commerce, taking into account the ecosystem of sustainable development, it is proposed to use three areas of its diagnosis:

1. economic (demonstrates the quality of e-business operation);

2. environmental (reflects the impact of a company on the environment);

3. social (demonstrates the level of interaction with personnel, clients and society as a whole).

If sustainability is not ensured, there will be some negative consequences, which can be a trigger for a shrinking ecosystem. In this regard, businesses should implement functions that take into account consumer preferences, which will make it as easy as possible to interact with them. The proliferation of e-commerce aims to increase the number of orders going to consumers, causing significant $\mathrm{CO}_{2}$ emissions and increasing traffic congestion in cities. B2C e-commerce delivery now accounts for a significant portion of total e-commerce shipments, causing increasing pollution [6]. This pollution is not expected to decrease in the near future, as there is a growing trend in the number of customers and retailers using the Internet. In addition, new businesses are being created day by day in the online marketplace, making serious demands on the distribution of goods that can damage the environment if appropriate measures are not taken. High emissions contribute to environmental pollution, affecting both the environment itself and the people who inhabit it. Consequently, e-commerce should pay special attention to environmental sustainability by seeking lower cost-dependent prices from logistics service providers and providing alternative transportation options for doing business whenever possible [7]. The primary goal of a retail company is to focus on economic returns to generate profits and revenues [8]. This can be achieved by making the necessary decisions to find possible trade-offs for the economy, the environment and society that add value. At the same time, neither a company nor a country can achieve sustainable economic development without putting the environment at risk. To be sustainable, businesses must balance their position with the sustainability aspects of e-commerce [9].

As previous studies have shown, there is a need to balance and deepen the scientific understanding of sustainable e-commerce in the virtual marketplace. These studies have left unexplored ways to integrate the three dimensions of e-commerce sustainability into the operation of a business model. Therefore, this study aims to fill this gap by forming a methodological toolkit for diagnosing the sustainability of e-commerce business mod- 
els. Therefore, the purpose of this study is to develop a comprehensive methodological approach to assessing the sustainability of the e-commerce business model based on the integration of key performance indicators into a single vector of business model sustainability. A distinctive feature of this study is the proposed methodological approach, which integrates a variety of tools into one set to assess business model sustainability based on a vector indicator. The obtained study results in the context of vector deviations indicate their equal importance in the process of forming a sustainable business model. The proposed vector approach makes it possible to forecast and evaluate the effects of various kinds of measures as well as to identify and implement the most effective tools for sustainable e-commerce business development.

\section{Literature Review}

The UN General Assembly has expressed its plans to harness the potential of ICT to advance trade by 2030 in the Sustainable Development Agenda and other internationally agreed development goals [10]. At the same time, it should be noted that it could accelerate progress according to all 17 Sustainable Development Goals (SDGs). E-commerce has direct relevance to several of these goals. For example, e-commerce can be used to help empower women as entrepreneurs and merchants [11,12]. E-commerce and digital commerce can support productive activities, decent job creation, entrepreneurship, creativity and innovation [13]. They can facilitate the formalization and growth of micro, small and medium-sized enterprises (MSMEs) in developing countries, including through access to ICT-enabled financial services, including web and mobile payments [14]. They can also facilitate the integration of MSMEs into value chains and markets (e.g., through the use of virtual markets) [15]. Moreover, e-commerce can help significantly increase developing countries' exports, including with the goal of doubling the share of least developed countries in world exports. However, the rapid adoption of ICT and e-commerce has a transformational effect creating both opportunities and challenges for developing countries, including the least developed countries [16]. In terms of opportunities, the use of ICT can reduce transaction costs and enable more goods and services to be delivered remotely. For example, the automation of customs declarations has been shown to reduce customs clearance time and shorten the time goods spend in transit [17]. Access to ICT platforms and devices allows a vendor from a developing country to reach more potential consumers in both domestic and foreign markets, acting in a more targeted and often less costly way than through traditional channels. At the same time, suppliers that increase their reliance on e-commerce can see a reduction in delivery costs, especially for electronic content. This affects global value chains as more inputs can be provided digitally, in turn making it easier to manage fragmented production networks [18]. Women-owned small and micro businesses can benefit from B2B, B2C and C2C transactions that use e-commerce platforms to reach domestic and foreign markets. Women entrepreneurs, who often have limitations in their access to capital, can take advantage of the ability of e-commerce to increase efficiency and profitability with limited investment [19].

Consumers can benefit from e-commerce in a variety of ways, both monetary and non-monetary. Web browsing, email inquiries and social media allow them to more easily compare prices and product features through reviews from other consumers [20]. They can also shop at their convenience or through online discounters. In addition, consumer choice expands when products that are far away can still be ordered. However, uneven access to ICTs can lead to an inequitable distribution of e-commerce benefits, bypassing those with low education and/or literacy, as well as MSMEs in rural areas or with limited connectivity [21].

Governments have a critical role to play in creating an environment conducive to maximizing the sustainability of such e-commerce opportunities [18]. Consideration of such policies can help leverage e-commerce for sustainable development. E-commerce policy should be coherent, and its goals should be well integrated with the goals of the national development agenda. E-commerce can support various other economic and social goals, 
among them high productivity, improved competitiveness, better access to information, increased transparency of regulations and more inclusive and equitable development [22]. While the role of governments is extremely important in creating an enabling environment, the involvement in effective dialogue of all relevant stakeholders is also important [23].

In the e-business model, sustainable development is characterized by certain aspects affecting different areas (economic, social and environmental). Applying the concept of sustainability to the e-commerce process can balance individual dimensions, such as impacting the level of efficiency and effectiveness (economic aspect) of a company, providing easier access to products or creating new jobs (social aspect) and having a better impact on the environment by reducing documents and waste (environmental aspect). This also identifies four factors, including "convenience of product return," "integrity of goods," "pre-booking of the delivery of goods" and "cost of delivery," as major factors that affect the sustainability of last mile delivery and are the deepest and most indispensable drivers of it [24]. Buyers, who are increasingly developing an environmental culture, prefer to purchase goods and services from manufacturers and suppliers who are interested in caring about the environment and the lives of people [25].

The current literature identifies the following main business models in the context of sustainable development that are applicable to e-commerce: products, services and technologies, product service and circular economy. The business model of e-commerce in the context of sustainable technology development includes cooperation between companies in order to develop and implement new environmentally friendly technologies to carry out their activities [26]. Technology can provide economic, social and environmental sustainability by virtue of its nature to reinforce a positive relationship between human needs and environmental constraints. Technology can be considered as a parameter leading to sustainability, focusing on the consumption of renewable energy, resource conservation, new pollution control methods and waste management [27].

The product service concept offers a new e-commerce business model that satisfies customer needs by offering a combination of products and services. The main idea of the product service model is to reduce the impact on the environment, which leads to sustainability by providing efficient services or product consumption. In this way, meeting customer requirements is based on innovative and sustainable solutions among all production activities [28]. The goal of the product service model is to reduce resource consumption and create products and services with fewer resources, less cost and less pollution [29].

The e-commerce business model in the context of the circular economy focuses on recycling. Its main goal is to provide opportunities and create competitive value for advanced welfare in society by considering the use of fewer materials, energy resources, etc. The business model of the circular economy focuses on the efficient allocation of resources, as well as the consumption of energy and resources [30]. It represents an environmentally friendly business model that promotes the use of sustainable methods with less negative impact on the environment. In terms of social sustainability, the business model of the circular economy provides new employment opportunities, equitable economic distribution and a global contribution to the overall well-being of society. The business model of the circular economy is defined in a way that embraces the various contributions as a "regenerative" system in which inputs of resources, waste, emissions and energy leaks are minimized by slowing down, closing and narrowing the cycles of material and energy resources [31]. This can be achieved in e-commerce through long-term design, maintenance, repair, reuse, recycling and renovation [32].

The modern stage of information revolution aims not only to introduce the latest technologies of interaction between subjects of socio-economic relations, but also to develop unified solutions to organize economic mechanisms of implementing global information business structures, which have become widely known as "e-commerce systems". E-commerce fundamentally changes business processes in enterprises and forms new business models, which contribute to improving the efficiency of businesses [33]. That is why the problems of developing methodological tools to assess e-commerce effectiveness, 
taking into account sustainability aspects, are becoming increasingly relevant. Paying tribute to the existing research on various aspects of e-commerce management, it should be noted that the issues of forming a system of key indicators for assessing the effectiveness of e-commerce business model sustainability remain underreported and require further scientific search. Therefore, this study aims to develop a comprehensive methodological approach to assessing e-commerce business model sustainability based on the integration of key performance indicators into a single vector of business model sustainability. To achieve this goal, the study generated the following hypotheses:

Hypothesis 1. The economic efficiency of e-commerce has a significant impact on the level of the business model sustainability of a company;

Hypothesis 2. The level of business model sustainability depends on the balance of e-commerce efficiency in different areas.

\section{Materials and Methods}

The methodology of this study is based on correlation, cluster and regression analysis of the sustainability of the business models of e-commerce companies. This study emphasizes that business model sustainability involves improving its effectiveness in three areas: economic, environmental and social. These areas have an impact on the proposed integrated vector of business model sustainability in the context of analyzing three indicators-Business model economic efficiency indicator (EcI), Business model environmental efficiency indicator (EnvI) and Business model social efficiency indicator (SocI). In order to confirm the formed assumption, inverse induction was used. For this purpose, key indicators of business model sustainability effectiveness-EcI, EnvI and SocI-are expressed as $x_{1}, x_{2}$ and $x_{3}$. Given the particular importance of sustainable business model effectiveness, forming the optimization model with respect to controlling influence can be expressed as follows:

$$
\max _{e_{3}} a S_{2} x_{3}-\beta E_{2}\left(t_{3}-t_{0}\right)-s_{1}-s_{2}-s_{3}
$$

The possibility of meeting the following condition should be considered:

$$
\begin{gathered}
P_{2}\left(x_{3}=1\right)=\chi_{3}\left(1-\exp ^{-\lambda_{3} s_{3}}\right) x_{2} \\
t_{3}=t_{2}+a_{3} \\
s_{3} \geq 0
\end{gathered}
$$

In this case, there is a fixed element in the form of: $t_{3}=t_{2}+a_{3}$, which is unaffected by the controlling influence in the context of sustainability $s_{3}$. At the same time:

$$
S_{2} x_{3}=1 \cdot P_{2}\left(x_{3}=1\right)=\chi_{3}\left(1-\exp ^{-\lambda_{3} s_{3}}\right) x_{2}
$$

Thus, the following can be deduced:

$$
\max _{s_{3} \geq 0} a \chi_{3}\left(1-\exp ^{-\lambda_{3} s_{3}}\right) x_{2}-s_{3}
$$

Based on the first-order conditions, the following solution can be derived:

$$
\begin{gathered}
s_{3}=\frac{1}{\lambda_{3}} \ln a \chi_{3} \lambda_{3}, \text { if } a \chi_{3} \lambda_{3}>1 \text { and } x_{2}=1, \\
s_{3}=0, \text { if } a \chi_{3} \lambda_{3} x_{2} \leq 1 .
\end{gathered}
$$


For the third direction, the optimal sustainability model $F_{3}(\cdot, \cdot, \cdot)$ of controlling influence $s_{3}$ is set as follows:

$$
\begin{gathered}
s_{3}=F_{3}\left(s_{2}, x_{2}, t_{2}\right)=\frac{1}{\lambda_{3}} \ln a \chi_{3} \lambda_{3}, \text { if } a \chi_{3} \lambda_{3}>1 \text { and } x_{2}=1, \\
s_{3}=F_{3}\left(s_{2}, x_{2}, t_{2}\right)=0, \text { if } a \chi_{3} \lambda_{3} x_{2} \leq 1 .
\end{gathered}
$$

The optimal sustainability model does not depend on the degree of controlling influence in the context of the second direction $s_{2}$, nor on the time to achieve the goals set $t_{2}$. At the same time, it depends on the level of efficiency in the context of sustainability in other areas. Therefore, an impact on the sustainability performance of the business model is required $s_{3}$ to ensure the continued effectiveness of e-commerce $\left(x_{2}=1\right)$ than in the case of a decrease in its level (c).

The optimal impact of business model sustainability on its economic efficiency is determined by the same principle in the direction of improving the effectiveness of business model sustainability:

$$
\max _{e_{2}} a S_{1} x_{3}-\beta S_{1}\left(t_{2}+a_{3}-t_{0}\right)-s_{1}-s_{2}-S_{1} s_{3}
$$

Given the need to meet the relevant conditions, this can be expressed as:

$$
S_{1} x_{3}=S_{1}\left(S_{2}\left(x_{3}\right)\right)=S_{1}\left(\chi_{3}\left(1-\exp ^{-\lambda_{3} s_{3}}\right) x_{2}\right)
$$

Based on optimizing the impact of sustainability on e-commerce business model efficiency $s_{3}$, which was defined earlier, it is possible to express the following:

$$
\begin{gathered}
S_{1} x_{3}=\chi_{3}\left(1-\frac{1}{a \chi_{3} \lambda_{3}}\right) P_{1}\left(x_{2}=1\right), \text { if } a \chi_{3} \lambda_{3}>1 \\
\text { and } S_{1} x_{3}=0, \text { if } a \chi_{3} \lambda_{3} \leq 1 . \\
S_{1} s_{3}=\frac{1}{\lambda_{3}} \ln \left(a \chi_{3} \lambda_{3}\right) P_{1}\left(x_{2}=1\right)=\frac{1}{\lambda_{3}} \ln \left(a \chi_{3} \lambda_{3}\right) \chi_{2}\left(1-\exp ^{-\lambda_{2} s_{2}}\right) x_{1}, \\
\text { if } a \chi_{3} \lambda_{3}>1, \text { and } S_{1} s_{3}=0, \text { if } a \chi_{3} \lambda_{3} \leq 1 .
\end{gathered}
$$

Provided that $a \chi_{3} \lambda_{3}>1$, forming optimal impact in the context of improving the effectiveness of business model sustainability $s_{2}$ can be reduced to:

$$
\max _{s_{2}}\left(a \chi_{3}-\frac{1}{\lambda_{3}}-\frac{1}{\lambda_{3}} \ln \left(a \chi_{3} \lambda_{3}\right) \chi_{2}\left(1-\exp ^{-\lambda_{2} s_{2}}\right) x_{1}-\beta S_{1}\left(t_{2}-t_{1}\right)-s_{2}\right.
$$

If one continues to follow the variable $t_{2}$, it can be argued that:

$$
\max _{s_{2} \geq 0}\left(a \chi_{3}-\frac{1}{\lambda_{3}}-\frac{1}{\lambda_{3}} \ln \left(a \chi_{3} \lambda_{3}\right) \chi_{2}\left(1-\exp ^{-\lambda_{2} s}\right) x_{1}-\frac{\beta}{\mu_{3}}\left(\gamma_{2} s_{2}-\delta_{2} s_{1}+a_{2}\right)-s_{2},\right.
$$

which can also be expressed as follows:

$$
\max _{s_{2} \geq 0}\left(a \chi_{3}-\frac{1}{\lambda_{3}}-\frac{1}{\lambda_{3}} \ln \left(a \chi_{3} \lambda_{3}\right) \chi_{2} \exp ^{-\lambda_{2} s_{2}} x_{1}-\left(\frac{\beta}{\mu_{3}} \gamma_{2}+1\right) s_{2}\right.
$$

Provided that $a \chi_{3} \lambda_{3} \leq 1$, the formation of the optimal impact in the context of improving the effectiveness of business model sustainability $s_{2}$ can be determined as follows:

$$
\max _{s_{2} \geq 0}-\frac{\beta}{\mu_{3}}\left(\gamma_{2} s_{2}-\delta_{2} s_{1}+a_{2}\right)-s_{2}
$$


This allows one to state that $x_{2}=0$. Provided that $a \chi_{3} \lambda_{3}>1$, one can state the formation of the optimal impact of improving business model sustainability in the context of economic efficiency:

$$
\begin{gathered}
s_{2}=F_{2}\left(s_{1}, x_{1}, t_{1}\right)=\frac{1}{\lambda_{3}} \ln \frac{\mu_{3} \lambda_{2} \chi_{2}\left(a \chi_{3}-\left(1+\ln \left(a \chi_{3} \lambda_{3}\right)\right) / \lambda_{3}\right)}{\beta \gamma_{2}+\mu_{3}}, \\
\text { if } \frac{\mu_{3} \lambda_{2} \chi_{2}\left(a \chi_{3}-\left(1+\ln \left(a \chi_{3} \lambda_{3}\right)\right) / \lambda_{3}\right)}{\beta \gamma_{2}+\mu_{3}}>1 \text { and } x_{1}=1 ; \\
s_{2}=F_{2}\left(s_{1}, x_{1}, t_{1}\right)=0, \text { if } \frac{\mu_{3} \lambda_{2} \chi_{2}\left(a \chi_{3}-\left(1+\ln \left(a \chi_{3} \lambda_{3}\right)\right) / \lambda_{3}\right)}{\beta \gamma_{2}+\mu_{3}} x_{1} \leq 1 .
\end{gathered}
$$

An important component of business model sustainability is the inclusion of impacts in the context of the social direction, taking into account the impacts identified above in the other two directions. The target function for finding $s_{1}$ can be expressed in this way:

$$
\max _{s_{1}} a S_{0} x_{3}-\beta S_{0}\left(t_{3}-t_{0}\right)-s_{1}-S_{0} s_{2}-S_{0} s_{3}
$$

It follows that:

$$
S_{0} x_{3}=S_{0}\left(S_{1}\left(S_{2}\left(x_{3}\right)\right)\right)=S_{0}\left(S_{1}\left(\chi_{3}\left(1-\exp ^{-\lambda_{3} s_{3}}\right) x_{2}\right)\right)
$$

Thus,

$$
\begin{gathered}
\left.S_{0} x_{3}=\chi_{3}\left(1-\frac{1}{a \chi_{3} \lambda_{3}}\right) S_{0}\left(P_{1}\left(x_{2}=1\right)\right)=\chi_{3}\left(1-\frac{1}{a \chi_{3} \lambda_{3}}\right) S_{0}\left(\left(1-\exp ^{-\lambda_{2} s_{2}}\right) x_{1}\right)\right), \\
\text { if } a \chi_{3} \lambda_{3}>1 \text { and } S_{0} s_{3}=0, \text { if } a \chi_{3} \lambda_{3} \leq 1 .
\end{gathered}
$$

Hence,

$$
\begin{gathered}
S_{0} x_{3}=\chi_{3}\left(1-\frac{1}{a \chi_{3} \lambda_{3}}\right)\left(1-\frac{\beta \gamma_{2}+\mu_{3}}{\mu_{3} \lambda_{2} \chi_{2}\left(a \chi_{3}-\left(1+\ln \left(a \chi_{3} \lambda_{3}\right)\right) / \lambda_{3}\right.}\right) P_{0}\left(x_{1}=1\right)=\chi_{1} \chi_{3}\left(1-\frac{1}{a \chi_{3} \lambda_{3}}\right) \\
\left(1-\frac{\beta \gamma_{2}+\mu_{3}\left(a x_{3} \lambda_{3}\right) / \lambda_{3}}{\mu_{3} \lambda_{2} \chi_{2}\left(a \chi_{3}-\left(1+\ln \left(a x^{-}\right.\right.\right.} \exp ^{-\lambda_{1} s_{1}} x_{0},\right. \\
\text { If } \frac{\mu_{3} \lambda_{2} \chi_{2}\left(a \chi_{3}-\left(1+\ln \left(a \chi_{3} \lambda_{3}\right)\right) / \lambda_{3}\right)}{\beta \gamma_{2}+\mu_{3}}>1 \text {, and } \\
S_{0} x_{3}=0, \text { if } \frac{\mu_{3} \lambda_{2} \chi_{2}\left(a \chi_{3}-\left(1+\ln \left(a \chi_{3} \lambda_{3}\right)\right) / \lambda_{3}\right)}{\beta \gamma_{2}+\mu_{3}} x_{1} \leq 1 \text { or } a \chi_{3} \lambda_{3} \leq 1 .
\end{gathered}
$$

As a result:

$$
\begin{gathered}
S_{0}\left(t_{3}-t_{0}\right)=S_{0}\left(t_{2}+a_{3}-t_{0}\right)=S_{0}\left(t_{2}-t_{1}\right)+S_{0}\left(t_{1}-t_{0}\right)+a_{3} \\
S_{0}\left(t_{1}-t_{0}\right)=S_{0}\left(\left(\gamma_{1} s_{1}+a_{2}\right) \varepsilon_{1}\right)=\frac{\gamma_{1} s_{1}+a_{2}}{\mu_{1}} \text { and } S_{0}\left(t_{2}-t_{1}\right) \\
=S_{0}\left(\gamma_{2} s_{2}-\delta_{2} s_{1}+a_{2}\right) \varepsilon_{2}=S_{0}\left(S_{1}\left(\left(\gamma_{2} s_{2}-\delta_{2} s_{1}+a_{2}\right) \varepsilon_{2}\right)\right)=\frac{1}{\mu_{2}} E_{0}\left(\gamma_{2} s_{2}-\delta_{2} s_{1}+a_{2}\right) .
\end{gathered}
$$

It can be expressed differently if

$$
\begin{gathered}
\frac{\mu_{3} \lambda_{2} \chi_{2}\left(a \chi_{3}-\left(1+\ln \left(a \chi_{3} \lambda_{3}\right)\right) / \lambda_{3}\right)}{\beta \gamma_{2}+\mu_{3}} x_{1}>1, \\
S_{0}\left(t_{2}-t_{1}\right)=\frac{a_{2}-\delta_{2} s_{1}}{\mu_{2}}+\frac{\gamma_{2}}{\mu_{2} \lambda_{2}} \ln \frac{\mu_{3} \lambda_{2} \chi_{2}\left(a \chi_{3}-\left(1+\ln \left(a \chi_{3} \lambda_{3}\right)\right) / \lambda_{3}\right)}{\left.\beta \gamma_{2}+\mu_{3}\right)} P_{0}\left(x_{1}=1\right) \\
=\frac{a_{2}-\delta_{2} s_{1}}{\mu_{2}}+\frac{\gamma_{2} \chi_{2} \lambda_{1}}{\mu_{2} \lambda_{2}} \ln \frac{\mu_{3} \lambda_{2} \chi_{2}\left(a \chi_{3}-\left(1+\ln \left(a \chi_{3} \lambda_{3}\right) / \lambda_{3}\right)\right.}{\beta \gamma_{2}+\mu_{3}} \exp ^{-\lambda_{1} s_{1}} x_{0}
\end{gathered}
$$

At the same time, if

$$
\begin{gathered}
\frac{\mu_{3} \lambda_{2} \chi_{2}\left(a \chi_{3}-\left(1+\ln \left(a \chi_{3} \lambda_{3}\right)\right) / \lambda_{3}\right)}{\beta \gamma_{2}+\mu_{3}} x_{1} \leq 1 \\
\text { or } a \chi_{3} \lambda_{3} \leq 1, S_{0}\left(t_{2}-t_{1}\right)=\frac{a_{2}-\delta_{2} e_{1}}{\mu_{2}} .
\end{gathered}
$$

In addition, in the case of

$$
\begin{gathered}
\frac{\mu_{3} \lambda_{2} \chi_{2}\left(a \chi_{3}-\left(1+\ln \left(a \chi_{3} \lambda_{3}\right)\right) / \lambda_{3}\right)}{\beta \gamma_{2}+\mu_{3}} x_{1}>1, \\
S_{0} s_{2}=\frac{1}{\lambda_{2}} \ln \frac{\mu_{3} \lambda_{2} \chi_{2}\left(a \chi_{3}-\left(1+\ln \left(a \chi_{3} \lambda_{3}\right)\right) / \lambda_{3}\right)}{\beta \gamma_{2}+\mu_{3}} P_{0}\left(x_{1}=1\right) \\
=\frac{\chi_{1}}{\lambda_{2}} \ln \frac{\mu_{3} \lambda_{2} \chi_{2}\left(a \chi_{3}-\left(1+\ln \left(a \chi_{3} \lambda_{3}\right)\right) / \lambda_{3}\right)}{\beta \gamma_{2}+\mu_{3}} \exp ^{-\lambda_{1} s_{1}} x_{0} .
\end{gathered}
$$


On the contrary, in the case of

$$
\frac{\mu_{3} \lambda_{2} \chi_{2}\left(a \chi_{3}-\left(1+\ln \left(a \chi_{3} \lambda_{3}\right)\right) / \lambda_{3}\right)}{\beta \gamma_{2}+\mu_{3}} x_{1} \leq 1, \text { or } a \chi_{3} \lambda_{3} \leq 1, s_{0} s_{2}=0 .
$$

Thus,

$$
\begin{aligned}
S_{0} s_{3}= & \frac{1}{\lambda_{3}} \ln \left(a \chi_{3} \lambda_{3}\right) P_{0}\left(x_{2}=1\right)=\frac{\chi_{2}}{\lambda_{3}} \ln \left(a \chi_{3} \lambda_{3}\right) S_{0}\left(\left(1-\exp ^{-\lambda_{2} s_{2}}\right) x_{1}\right) \\
= & \frac{\chi_{2}}{\lambda_{3}} \ln \left(a \chi_{3} \lambda_{3}\right) 1-1-\left(\frac{\beta \gamma_{2}+\mu_{3}}{\left.\frac{\mu_{3} \lambda_{2} \chi_{2}\left(a \chi_{3}-\left(1+\ln \left(a \chi_{3} \lambda_{3}\right)\right)\right.}{\lambda_{3}}\right)} P_{0}\left(x_{2}=1\right)\right. \\
& =\frac{\chi_{1} \chi_{2}}{\lambda_{2}} \ln \left(a \chi_{3} \lambda_{3}\right)\left(1-\frac{\beta \gamma_{2}+\mu_{3}}{\frac{\mu_{3} \lambda_{2} \chi_{2}\left(a \chi_{3}-\left(1+\ln \left(a \chi_{3} \lambda_{3}\right)\right)\right.}{\lambda_{3}}}\right)\left(\exp ^{-\lambda_{1} s_{1}} x_{0}\right)
\end{aligned}
$$

In the case of

$$
\frac{\mu_{3} \lambda_{2} \chi_{2}\left(a \chi_{3}-\left(1+\ln \left(a \chi_{3} \lambda_{3}\right)\right) / \lambda_{3}\right)}{\beta \gamma_{2}+\mu_{3}} x_{1}>1
$$

In the case of

$$
\frac{\mu_{3} \lambda_{2} \chi_{2}\left(a \chi_{3}-\left(1+\ln \left(a \chi_{3} \lambda_{3}\right)\right) / \lambda_{3}\right)}{\beta \gamma_{2}+\mu_{3}} x_{1} \leq 1 \text { or } a \chi_{3} \lambda_{3} \leq 1, s_{0} s_{3}=0 .
$$

Based on the complex integration of these expressions into a single target function in order to determine the optimal sustainability model in the context of $s_{1}$, the following is obtained to determine $s_{1}$ :

$$
\max _{s_{2} \geq 0}-A \exp ^{-\lambda_{1} s_{1}}-B s_{1}
$$

where,

$$
B=1-\beta\left(\frac{\delta_{2}}{\mu_{2}}-\frac{\gamma_{1}}{\mu_{1}}\right),
$$

whereas in the case of

$$
\begin{gathered}
\frac{\mu_{3} \lambda_{2} \chi_{2}\left(a \chi_{3}-\left(1+\ln \left(a \chi_{3} \lambda_{3}\right)\right) / \lambda_{3}\right)}{\beta \gamma_{2}+\mu_{3}}>1 \\
A=-a \chi_{1} \chi_{3}\left(1-\frac{1}{a \chi_{3} \lambda_{3}}\right)\left(1-\frac{\beta \gamma_{2}+\mu_{3}}{\left.\frac{\mu_{3} \lambda_{2} \chi_{2}\left(a \chi_{3}-\left(1+\ln \left(a \chi_{3} \lambda_{3}\right)\right)\right)}{\lambda_{3}}\right)} x_{0}-\right. \\
\beta\left(\frac{\gamma_{2} \chi_{1}}{\lambda_{2} \mu_{2}} \ln \frac{\mu_{3} \lambda_{2} \chi_{2}\left(a \chi_{3}-\left(1+\ln \left(a \chi_{3} \lambda_{3}\right)\right) / \lambda_{3}\right)}{\beta \gamma_{2}+\mu_{3}} x_{0}\right. \\
\left.+\frac{\chi_{1}}{\lambda_{2}} \ln \frac{\mu_{3} \lambda_{2} \chi_{2}\left(a \chi_{3}-\left(1+\ln \left(a \chi_{3} \lambda_{3}\right)\right) / \lambda_{3}\right)}{\beta \gamma_{2}+\mu_{3}} x_{0}+\frac{\chi_{1} \chi_{2}}{\lambda_{2}} \ln \left(a \chi_{3} \lambda_{3}\right)\left(1-\frac{\beta \gamma_{2}+\mu_{3}}{\frac{\mu_{3} \lambda_{2} \chi_{2}\left(a \chi_{3}-\left(1+\ln \left(a x_{3} \lambda_{3}\right)\right)\right)}{\lambda_{3}}} x_{0}\right)\right),
\end{gathered}
$$

and in the case of

$$
\frac{\mu_{3} \lambda_{2} \chi_{2}\left(a \chi_{3}-\left(1+\ln \left(a \chi_{3} \lambda_{3}\right)\right) / \lambda_{3}\right)}{\beta \gamma_{2}+\mu_{3}} x_{1} \leq 1 \text { or } a \chi_{3} \lambda_{3} \leq 1 A=0 .
$$

Based on the above, one can determine that the optimal level of the impact of business model sustainability, in the direction of economic efficiency and in the case of $A \lambda_{1} / B>1$ and $B>0$, will correspond to $s_{1}=\frac{1}{\lambda_{3}} \ln \frac{A \lambda_{1}}{B}$. At the same time, in the case of $A \lambda_{1} \leq B$ and $\geq 0$, it will be $s_{1}=0$. Therefore, it is possible to determine the lack of a comprehensive sustainability model in e-commerce if $B<0$ or in the case of $B=0$ and $A>0$. In this study, the assumption is made that such a situation is not possible in real operating conditions.

The level of business model sustainability in the field of e-commerce, based on the directions of economic efficiency (EcI), environmental efficiency (EnvI) and social efficiency (SocI), is determined in this study in the form of a vector value [34].

The level of business model sustainability in the proposed methodological approach can be considered a benchmark if $\overrightarrow{S V}=(1 ; 1 ; 1)$. Therefore, this study assumes that the deviation of the business model efficiency vector demonstrates the deviation from the level of its benchmark sustainability. Conversely, approaching the reference vector demonstrates the strengthening of its sustainability level (Figure 1). 


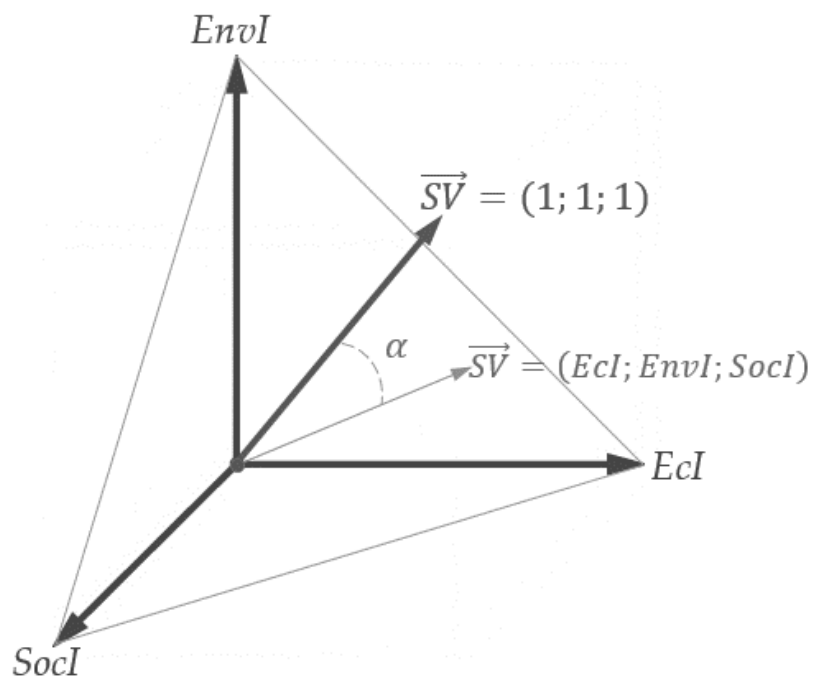

Figure 1. Scheme of business model sustainability vector construction. (Source: own development based on data from [35]).

Figure 1 shows the scheme of determining the vector of sustainable business model based on the proposed indicators (directions). The value of the vector of sustainable business model $\overrightarrow{S V}=$ (EcI; EnvI; SocI) is defined as the diagonal of a rectangular parallelepiped, which is created by the coordinates of the vectors $\overrightarrow{\mathrm{ECI}}_{i} ; \overrightarrow{\mathrm{EnvI}}_{j} ; \overrightarrow{\mathrm{SocI}}_{k}$ as follows:

$$
|\overrightarrow{S V}|=\sqrt{\mathrm{EcI}^{2}+\mathrm{EnvI}^{2}+\mathrm{SocI}^{2}}
$$

where,

$\overrightarrow{S V}$ - the length of Business model sustainability vector;

EcI-Business model economic efficiency indicator;

EnvI-Business model environmental efficiency indicator;

SocI-Business model social efficiency indicator.

Values of the indicators EcI, EnvI and SocI, according to the specified model, are determined by calculating the arithmetic average of the indicator, which is included in the structure of these indicators. For example, the value EcI is determined on the basis of such normalized indicators as the coefficient of financial independence $\left(i n d_{1}\right)$, absolute liquidity ratio $\left(i n d_{2}\right)$ and sales profitability $\left(i n d_{3}\right)$. The level of EnvI is defined on the basis of such normalized indicators as the efficiency of investment in environmental innovation (ind $\left.{ }_{4}\right)$, recycling rate $\left(i n d_{5}\right)$ and the index of energy-saving technologies $\left(i n d_{6}\right)$. SocI includes such indicators as the rate of return $\left(i n d_{7}\right)$, turnover rate $\left(i n d_{8}\right)$ and the number of programs and projects for vulnerable populations $\left(i n d_{9}\right)$.

Thus, the level of business model sustainability is the angle between the vector obtained from the results of assessing its effectiveness in the three directions and the reference vector, which is determined by the formula.

$$
\left\|1^{`}\right\|=\sqrt{1^{2}+1^{2}+1^{2}},
$$

The angle formed between the sustainability vectors of the business model can be determined in degrees by the following formula [34]:

$$
\alpha=\arccos \frac{\mathrm{EcI}+\mathrm{EnvI}+\mathrm{SocI}}{\sqrt{n} \cdot \sqrt{\mathrm{EcI}^{2}+\mathrm{EnvI}^{2}+\mathrm{Socl}^{2}}},
$$


where, $\alpha$-the angle between the vector obtained by assessing the effectiveness of the business model in the three directions, and the reference vector of its sustainability; $\mathrm{n}$ - the number of indicators (directions) of diagnosing the level of business model sustainability.

This angle is between $0<\alpha<\alpha_{\max }$, where $\alpha_{\max }$ can be defined as follows:

$$
\alpha_{\max }=\arccos \frac{1}{\sqrt{3}}
$$

The resulting indicator can be interpreted as follows: the closer the arccosine value is to 1, the higher the level of business model sustainability. In order to determine this Business model sustainability level (BMSL), it is necessary to bring the obtained value to $(0 ; 1)$ based on this formula:

$$
B M S L=\frac{1-\frac{\alpha}{\alpha_{\max }}-\frac{1-\frac{45}{\pi} \arccos \frac{1}{\sqrt{3}}}{\alpha_{\max }}}{1-\frac{1-\frac{45}{\pi} \arccos \frac{1}{\sqrt{3}}}{\alpha_{\max }}}
$$

The application of correlation analysis allowed for identification of the relationships between the studied indicators as well as the vector of business model sustainability. Clustering of the studied companies is necessary to identify groups of companies that have similar characteristics by the studied business model sustainability indicators. At the same time, regression analysis was used for the modeling in the context of determining the key areas of improving the effectiveness of the sustainable business model. In this study, the use of correlation, cluster and regression analysis is dictated by the feasibility of their integrated use for comprehensive consideration of factors affecting business model sustainability.

The study was conducted on the materials of 23 Russian online stores: "bonprix.ru", "exist.ru”, " goldapple.ru”, "goods.ru”, “hm.com", “holodilnik.ru”, "ikea.com”, “kolesadarom.ru", "komus.ru", "leroymerlin.ru", "onlinetrade.ru", "re-store.ru", "sbermarket.ru”, "shop.mts.ru", "sima-land.ru", "sportmaster.ru", "sunlight.net", "svyaznoy.ru", "technopoint.ru", "utkonos.ru", "vkusvill.ru", "vprok.ru" and "vseinstrumenti.ru". The key criteria for selecting companies were three indicators: online sales volume, number of orders and average check. These indicators demonstrate the leading positions of e-commerce companies, so the effectiveness of their sustainable business model may have a significant impact on the Russian market. A brief characteristic of the studied companies in the context of the selection criteria is given in Table 1 .

When selecting companies for the study, the key criteria were the volume of online sales (from USD 75 million), the number of orders (from 1 million) and the average check (from USD 20). Thus, e-commerce companies with leading positions on the Russian market were selected for the study.

Table 1. Indicators of the studied companies according to the selection criteria.

\begin{tabular}{ccccc}
\hline No. & Online Store & $\begin{array}{c}\text { Online Sales, } \\
\text { Mln USD }\end{array}$ & $\begin{array}{c}\text { Number of } \\
\text { Orders, } \\
\text { Thousand Units }\end{array}$ & $\begin{array}{c}\text { Average Check, } \\
\text { USD }\end{array}$ \\
\hline 1 & vseinstrumenti.ru & 595.28 & 7830 & 76.02 \\
\hline 2 & ikea.com & 571.2 & 2550 & 224 \\
\hline 3 & leroymerlin.ru & 528.92 & 4460 & 118.58 \\
\hline 4 & sima-land.ru & 523.6 & 4280 & 122.36 \\
\hline
\end{tabular}


Table 1. Cont.

\begin{tabular}{|c|c|c|c|c|}
\hline No. & Online Store & $\begin{array}{l}\text { Online Sales, } \\
\text { Mln USD }\end{array}$ & $\begin{array}{c}\text { Number of } \\
\text { Orders, } \\
\text { Thousand Units }\end{array}$ & $\begin{array}{c}\text { Average Check, } \\
\text { USD }\end{array}$ \\
\hline 5 & svyaznoy.ru & 331.1 & 1840 & 179.9 \\
\hline 6 & onlinetrade.ru & 322.7 & 3560 & 90.58 \\
\hline 7 & sportmaster.ru & 281.54 & 6370 & 44.24 \\
\hline 8 & shop.mts.ru & 273.7 & 1070 & 255.78 \\
\hline 9 & sbermarket.ru & 245.98 & 5330 & 46.2 \\
\hline 10 & komus.ru & 245.84 & 2180 & 112.84 \\
\hline 11 & technopoint.ru & 232.4 & 1860 & 124.88 \\
\hline 12 & utkonos.ru & 229.18 & 2660 & 86.1 \\
\hline 13 & vprok.ru & 209.86 & 3620 & 57.96 \\
\hline 14 & holodilnik.ru & 200.2 & 1280 & 392.56 \\
\hline 15 & exist.ru & 193.62 & 5130 & 37.8 \\
\hline 16 & vkusvill.ru & 189.7 & 9600 & 20.74 \\
\hline 17 & kolesa-darom.ru & 187.88 & 1437 & 221.06 \\
\hline 18 & bonprix.ru & 183.96 & 3520 & 52.22 \\
\hline 19 & sunlight.net & 181.16 & 2280 & 79.52 \\
\hline 20 & goods.ru & 169.4 & 2310 & 73.36 \\
\hline 21 & re-store.ru & 159.18 & 1328 & 558.46 \\
\hline 22 & hm.com & 120.12 & 2050 & 58.66 \\
\hline 23 & goldapple.ru & 76.86 & 1480 & 51.94 \\
\hline
\end{tabular}

Source: own development based on the materials of the companies.

\section{Results}

To determine the key performance indicators of the studied companies in the field of e-commerce in the context of sustainability, a diagnosis was made according to the formed system of nine constituent indicators. The results of this diagnosis are shown in Table 2.

Since the obtained indicators are calculated differently, it is necessary to carry out their normalization in order to bring them to a single scale. The results of normalizing the obtained results are shown in Table 3.

Table 2. System of performance indicators of a sustainable e-commerce business model.

\begin{tabular}{cccccccccc}
\hline $\begin{array}{c}\text { E-Commerce } \\
\text { Company }\end{array}$ & ind $_{1}$ & ind $_{2}$ & ind $_{3}$ & ind $_{4}$ & ind $_{5}$ & ind $_{6}$ & ind $_{7}$ & ind $_{8}$ & ind $_{9}$ \\
\hline goldapple.ru & 0.12 & 0.41 & 0.27 & 0.03 & 0.02 & 0.02 & 4 & 0.7 & 0.01 \\
\hline vprok.ru & 0.17 & 0.23 & 0.21 & 0.07 & 0.02 & 0.03 & 7 & 0.27 & 0.02 \\
\hline vkusvill.ru & 0.05 & 0.04 & 0.28 & 0.01 & 0 & 0.01 & 7 & 0.23 & 0 \\
\hline goods.ru & 0.07 & 0.42 & 0.28 & 0.07 & 0.01 & 0.03 & 3 & 0.24 & 0.01 \\
\hline hm.com & 0.22 & 0.08 & 0.16 & 0.03 & 0.04 & 0.04 & 5 & 0.13 & 0 \\
\hline
\end{tabular}


Table 2. Cont.

\begin{tabular}{|c|c|c|c|c|c|c|c|c|c|}
\hline $\begin{array}{c}\text { E-Commerce } \\
\text { Company }\end{array}$ & $i^{i n d} d_{1}$ & $i_{n d}$ & $\operatorname{ind}_{3}$ & ind $_{4}$ & $\operatorname{ind}_{5}$ & $\operatorname{ind}_{6}$ & $i d_{7}$ & ind $_{8}$ & ind $_{9}$ \\
\hline holodilnik.ru & 0.27 & 0.35 & 0.31 & 0.07 & 0.01 & 0.09 & 6 & 0.27 & 0.01 \\
\hline utkonos.ru & 0.27 & 0.34 & 0.37 & 0.1 & 0.02 & 0.01 & 2 & 0.47 & 0 \\
\hline kolesa-darom.ru & 0.2 & 0.25 & 0.34 & 0.17 & 0.01 & 0.05 & 2 & 0.39 & 0 \\
\hline komus.ru & 0.06 & 0.13 & 0.25 & 0.14 & 0.01 & 0.05 & 1 & 0.25 & 0 \\
\hline re-store.ru & 0.27 & 0.31 & 0.21 & 0.06 & 0.01 & 0.07 & 1 & 0.4 & 0 \\
\hline onlinetrade.ru & 0.21 & 0.24 & 0.4 & 0.11 & 0.03 & 0.04 & 2 & 0.95 & 0.03 \\
\hline vseinstrumenti.ru & 0.17 & 0.16 & 0.36 & 0.23 & 0.02 & 0.03 & 1 & 0.77 & 0.01 \\
\hline sbermarket.ru & 0.12 & 0.11 & 0.25 & 0.16 & 0.00 & 0.01 & 0 & 0.2 & 0 \\
\hline exist.ru & 0.09 & 0.08 & 0.27 & 0.03 & 0.02 & 0.01 & 0 & 0.33 & 0 \\
\hline ikea.com & 0.14 & 0.13 & 0.27 & 0.17 & 0.02 & 0.02 & 1 & 0.58 & 0 \\
\hline svyaznoy.ru & 0.16 & 0.07 & 0.41 & 0.14 & 0.03 & 0.06 & 6 & 0.43 & 0.02 \\
\hline sunlight.net & 0.16 & 0.37 & 0.21 & 0.04 & 0.02 & 0.02 & 1 & 0.88 & 0.02 \\
\hline bonprix.ru & 0.22 & 0.41 & 0.36 & 0.23 & 0.03 & 0.03 & 8 & 0.35 & 0.05 \\
\hline technopoint.ru & 0.19 & 0.08 & 0.49 & 0.16 & 0.03 & 0.07 & 7 & 0.51 & 0.03 \\
\hline sima-land.ru & 0.16 & 0.16 & 0.33 & 0.21 & 0.02 & 0.02 & 1 & 0.7 & 0.01 \\
\hline sportmaster.ru & 0.18 & 0.08 & 0.46 & 0.16 & 0.03 & 0.07 & 6 & 0.49 & 0.02 \\
\hline shop.mts.ru & 0.16 & 0.53 & 0.36 & 0.04 & 0.02 & 0.02 & 5 & 0.92 & 0.01 \\
\hline leroymerlin.ru & 0.38 & 0.35 & 0.33 & 0.1 & 0.02 & 0.04 & 1 & 0.97 & 0.02 \\
\hline
\end{tabular}

Source: own development based on the materials of the companies.

Table 3. Normalized performance indicators of a sustainable e-commerce business model.

\begin{tabular}{cccccccccc}
\hline $\begin{array}{c}\text { E-Commerce } \\
\text { Company }\end{array}$ & ind $_{1}$ & ind $_{2}$ & ind $_{3}$ & ind $_{4}$ & ind $_{5}$ & ind $_{6}$ & ind $_{7}$ & ind $_{8}$ & ind $_{9}$ \\
\hline goldapple.ru & 0.318 & 0.974 & 0.440 & 0.091 & 0.500 & 0.125 & 0.571 & 0.695 & 0.333 \\
\hline vprok.ru & 0.545 & 0.500 & 0.200 & 0.273 & 0.500 & 0.250 & 1.000 & 0.171 & 0.667 \\
\hline vkusvill.ru & 0.000 & 0.000 & 0.480 & 0.000 & 0.000 & 0.000 & 1.000 & 0.122 & 0.000 \\
\hline goods.ru & 0.091 & 1.000 & 0.480 & 0.273 & 0.250 & 0.250 & 0.429 & 0.134 & 0.333 \\
\hline hm.com & 0.773 & 0.105 & 0.000 & 0.091 & 1.000 & 0.375 & 0.714 & 0.000 & 0.000 \\
\hline holodilnik.ru & 1.000 & 0.816 & 0.600 & 0.273 & 0.250 & 1.000 & 0.857 & 0.171 & 0.333 \\
\hline utkonos.ru & 1.000 & 0.789 & 0.840 & 0.409 & 0.500 & 0.000 & 0.286 & 0.415 & 0.000 \\
\hline kolesa-darom.ru & 0.682 & 0.553 & 0.720 & 0.727 & 0.250 & 0.500 & 0.286 & 0.317 & 0.000 \\
\hline komus.ru & 0.045 & 0.237 & 0.360 & 0.591 & 0.250 & 0.500 & 0.143 & 0.146 & 0.000 \\
\hline re-store.ru & 1.000 & 0.711 & 0.200 & 0.227 & 0.250 & 0.750 & 0.143 & 0.329 & 0.000 \\
\hline onlinetrade.ru & 0.727 & 0.526 & 0.960 & 0.455 & 0.750 & 0.375 & 0.286 & 1.000 & 1.000 \\
\hline vseinstrumenti.ru & 0.545 & 0.316 & 0.800 & 1.000 & 0.500 & 0.250 & 0.143 & 0.780 & 0.333 \\
\hline sbermarket.ru & 0.318 & 0.184 & 0.360 & 0.682 & 0.000 & 0.000 & 0.000 & 0.085 & 0.000 \\
\hline exist.ru & 0.182 & 0.105 & 0.440 & 0.091 & 0.500 & 0.000 & 0.000 & 0.244 & 0.000 \\
\hline
\end{tabular}


Table 3. Cont.

\begin{tabular}{cccccccccc}
\hline $\begin{array}{c}\text { E-Commerce } \\
\text { Company }\end{array}$ & ind $_{1}$ & ind $_{2}$ & ind $_{3}$ & ind $_{4}$ & ind $_{5}$ & ind $_{6}$ & ind $_{7}$ & ind $_{8}$ & ind $_{9}$ \\
\hline ikea.com & 0.409 & 0.237 & 0.440 & 0.727 & 0.500 & 0.125 & 0.143 & 0.549 & 0.000 \\
\hline svyaznoy.ru & 0.500 & 0.079 & 1.000 & 0.591 & 0.750 & 0.625 & 0.857 & 0.366 & 0.667 \\
\hline sunlight.net & 0.500 & 0.868 & 0.200 & 0.136 & 0.500 & 0.125 & 0.143 & 0.915 & 0.667 \\
\hline bonprix.ru & 0.773 & 0.974 & 0.800 & 1.000 & 0.750 & 0.250 & 1.143 & 0.268 & 1.667 \\
\hline technopoint.ru & 0.636 & 0.105 & 1.320 & 0.682 & 0.750 & 0.750 & 1.000 & 0.463 & 1.000 \\
\hline sima-land.ru & 0.500 & 0.316 & 0.680 & 0.909 & 0.500 & 0.125 & 0.143 & 0.695 & 0.333 \\
\hline sportmaster.ru & 0.591 & 0.105 & 1.200 & 0.682 & 0.750 & 0.750 & 0.857 & 0.439 & 0.667 \\
\hline shop.mts.ru & 0.500 & 1.289 & 0.800 & 0.136 & 0.500 & 0.125 & 0.714 & 0.963 & 0.333 \\
\hline leroymerlin.ru & 1.500 & 0.816 & 0.680 & 0.409 & 0.500 & 0.375 & 0.143 & 1.024 & 0.667 \\
\hline
\end{tabular}

Source: own development based on the materials of the companies.

On the basis of the formed system of key indicators, diagnostics of the studied companies and normalization of the data, it is possible to determine the integral indicators of the proposed sustainable business model. Each indicator is formed on the basis of three indicators; that is, the nine indicators of the diagnostics became the components of three comprehensive indicators, which essentially form the axis of the sustainable business efficiency model in e-commerce proposed in this study. The results obtained for the three indicators are shown in Figure 2.

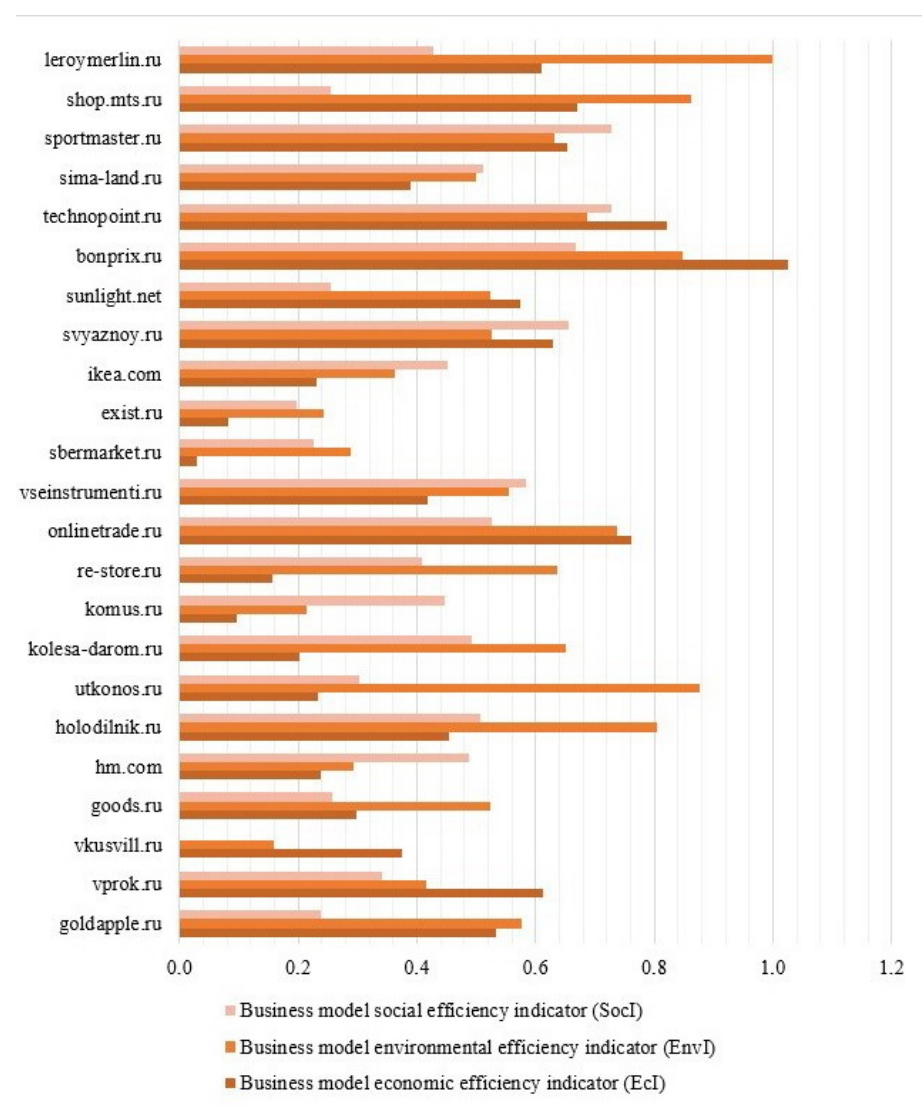

Figure 2. Sustainable business model performance indicators for the studied e-commerce companies. (Source: own development.) 
The assessment of business model sustainability provides an opportunity to identify leaders and outsiders among the studied e-commerce companies in the context of areas such as economic, environmental and social efficiency. For example, the leader in the environmental indicator of business model sustainability is vseinstrumenti.ru, while the outsider is komus.ru. However, given the fact that each of the companies has different levels of performance in each of the three areas, it is required to determine the level of sustainability performance as a comprehensive integral indicator. Such an indicator in this study is the vector of business model sustainability. In this case, there is a need to determine the most significant indicators for e-commerce companies. To this end, a correlation analysis was conducted, the results of which are visualized in the form of a matrix in Figure 3.

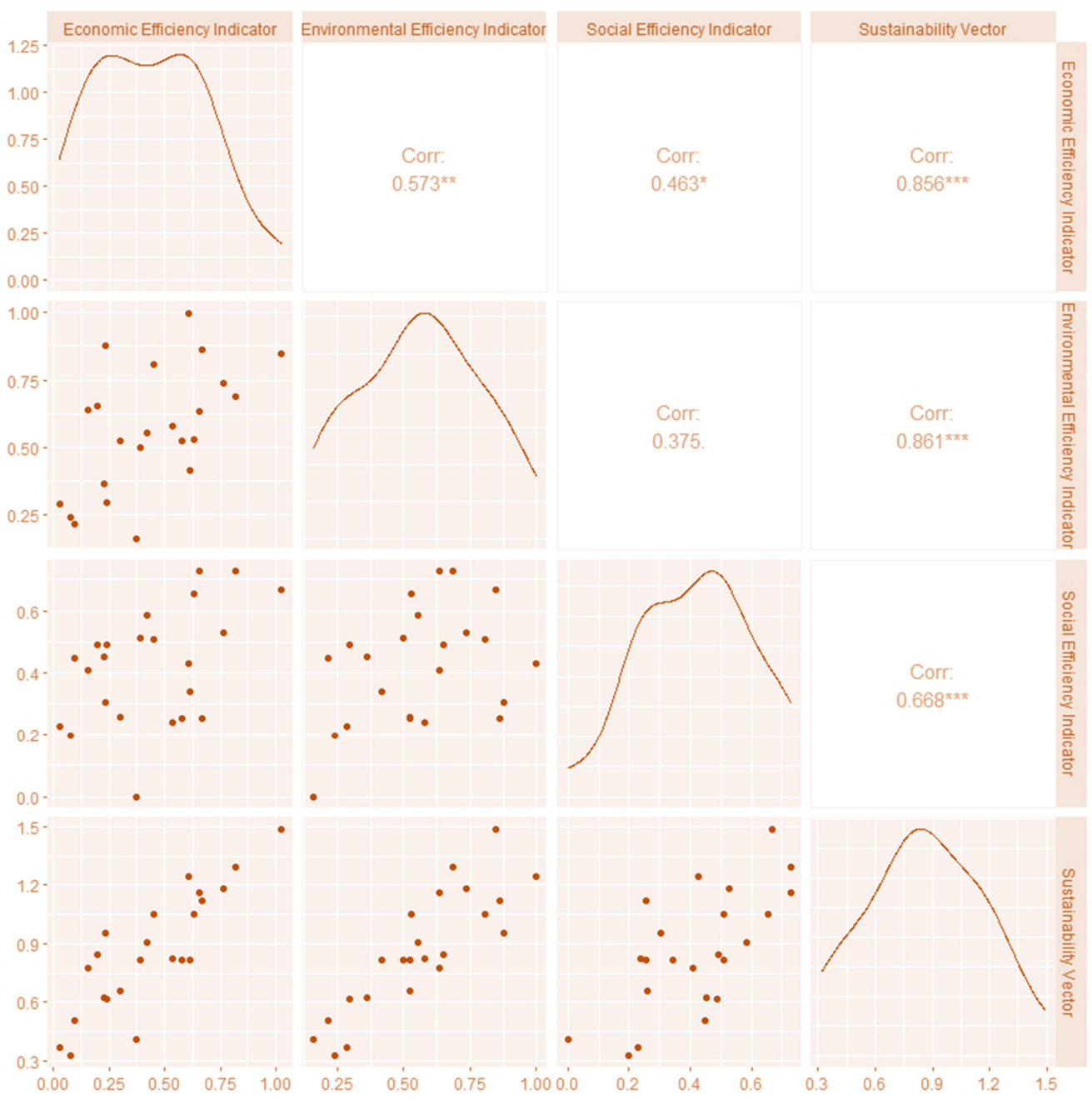

Figure 3. Correlation of constituent indicators and vector of sustainable business model of the studied e-commerce companies. $\left({ }^{*}: p \leq 0.05 ;{ }^{* *}: p \leq 0.01 ;{ }^{* * *}: p \leq 0.001\right.$; Source: own development).

The correlation analysis allows one to allocate the economic and ecological components of the sustainable business model as the most significant in the context of forming the complex sustainability vector. This is confirmed by the correlation indicators of economic and ecological efficiency of the sustainable business model (0.86) with its complex vector. This allows one to reject the first hypothesis, since this correlation analysis indicates equal influence of both economic and environmental components of the sustainable e-commerce business model vector. Less significant, but with a sufficient level of correlation with the complex vector of business model sustainability, is the social direction of 0.69 . At the same time, there is no significant relationship between the studied directions (factors) within the 
model. This provides an opportunity for regression modeling. However, it is not advisable to develop one regression model for all e-commerce companies, as its application in practice can significantly distort the forecast indicators given the large difference in the indicators of the studied companies. To compensate for this limitation, a cluster analysis was conducted (Figure 4), which allowed for grouping the companies under study according to the results of the indicators obtained in three areas.

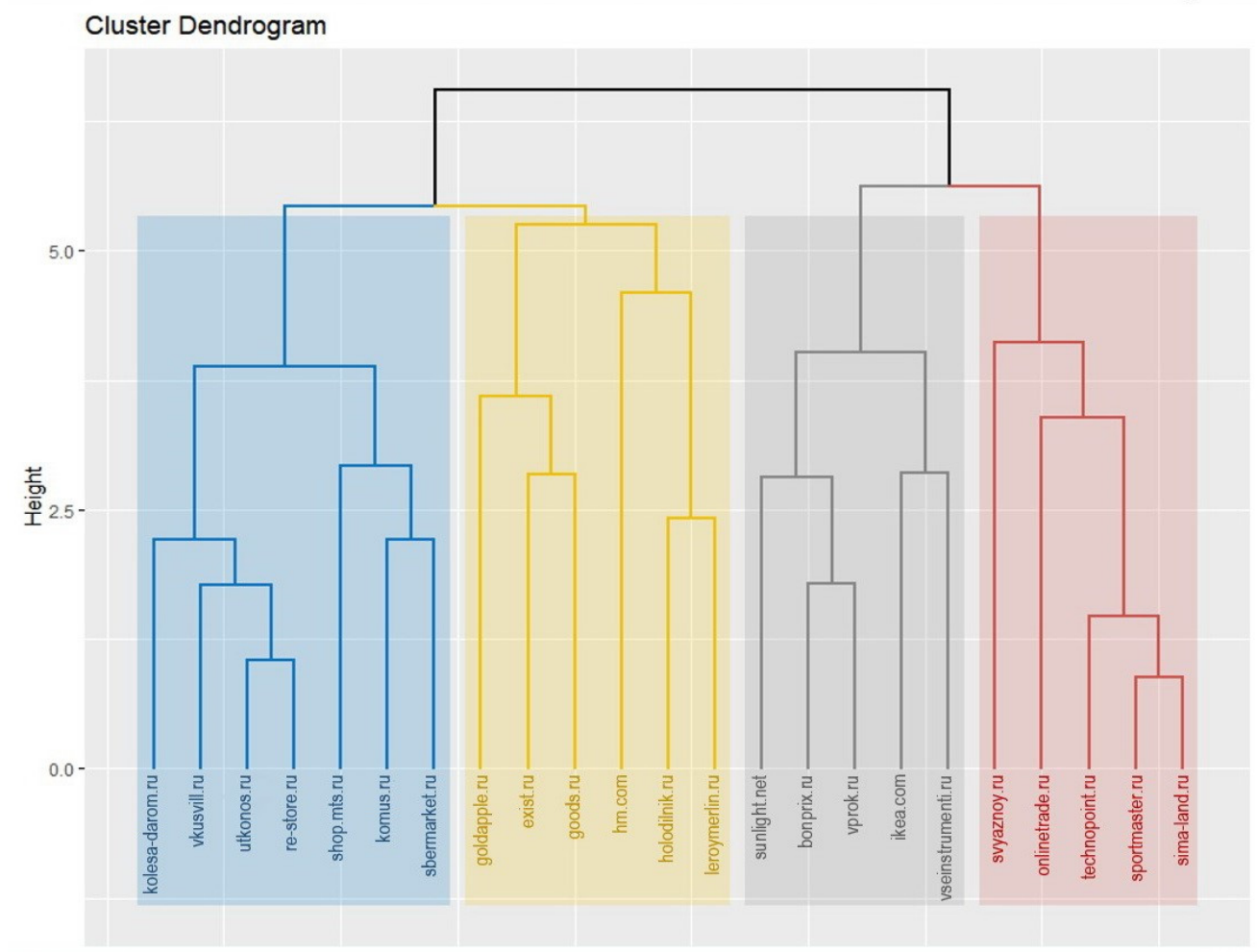

Figure 4. Dendrogram of the hierarchical clustering of the studied e-commerce companies. (Source: own development.)

The clustering allowed for the identification of four clusters of e-commerce companies, which are formed according to the parameters of the sustainable business model in the context of its economic, environmental and social effectiveness. Comparing the results of clustering and sustainability vectors of the studied e-commerce companies, one can say that the majority of companies in the blue cluster are characterized by a low level of sustainability of the business model, while those in the red cluster, on the contrary, are characterized by the highest.

Taking into account the formed clusters of the studied e-commerce companies, a regression analysis was carried out. Its main indicators are shown in Table 4.

For the first and third clusters, the most significant is the environmental factor (impact on the external environment). For the second and fourth clusters, the most significant is the economic efficiency of e-commerce. For all clusters, the least significant is the social factor. For all coefficients, the $p$-value $>0.05$. For the fourth (red) cluster of e-commerce companies, the economic factor plays a significant role. Given the fact that this cluster includes e-commerce companies, which have the highest sustainability indicators in the form of a vector, this composition of the model parameters is logical. The conducted regression analysis demonstrates the applicability of the formed models (Table 5). 
Table 4. Indicators of factor regression analysis of sustainable business model vector of the studied companies in the field of e-commerce by clusters.

\begin{tabular}{|c|c|c|c|c|c|c|c|}
\hline Group & Factor & Coefficients & $\begin{array}{l}\text { Standard } \\
\text { Error }\end{array}$ & $t$-Statistics & $p$-Value & $\begin{array}{c}\text { Lower } \\
95 \%\end{array}$ & Higher $95 \%$ \\
\hline \multirow{4}{*}{ Cluster 1} & $\begin{array}{c}\mathrm{Y}- \\
\text { intersection }\end{array}$ & 0.0887 & 0.0330 & 2.6904 & 0.0744 & -0.0162 & 0.1936 \\
\hline & EcI & 0.5401 & 0.0772 & 6.9961 & 0.0060 & 0.2944 & 0.7857 \\
\hline & EnvI & 0.6584 & 0.0536 & 12.2939 & 0.0012 & 0.4879 & 0.8288 \\
\hline & SocI & 0.4553 & 0.0941 & 4.8373 & 0.0168 & 0.1558 & 0.7549 \\
\hline \multirow{4}{*}{ Cluster 2} & $\begin{array}{c}\mathrm{Y}- \\
\text { intersection }\end{array}$ & 0.0118 & 0.0167 & 0.7073 & 0.5527 & -0.0602 & 0.0839 \\
\hline & EcI & 0.6152 & 0.0642 & 9.5771 & 0.0107 & 0.3388 & 0.8916 \\
\hline & EnvI & 0.6058 & 0.0455 & 13.3033 & 0.0056 & 0.4099 & 0.8017 \\
\hline & SocI & 0.5665 & 0.0463 & 12.2245 & 0.0066 & 0.3671 & 0.7659 \\
\hline \multirow{4}{*}{ Cluster 3} & $\begin{array}{c}\mathrm{Y}- \\
\text { intersection }\end{array}$ & 0.0346 & 0.0117 & 2.9487 & 0.2081 & -0.1146 & 0.1839 \\
\hline & EcI & 0.5801 & 0.0307 & 18.9010 & 0.0337 & 0.1901 & 0.9701 \\
\hline & EnvI & 0.6147 & 0.0598 & 10.2750 & 0.0218 & -0.1454 & 1.3748 \\
\hline & SocI & 0.5032 & 0.0356 & 14.1381 & 0.0450 & 0.0510 & 0.9555 \\
\hline \multirow{4}{*}{ Cluster 4} & $\begin{array}{c}\mathrm{Y}- \\
\text { intersection }\end{array}$ & 0.0208 & 0.0101 & 2.0657 & 0.2870 & -0.1072 & 0.1488 \\
\hline & EcI & 0.5965 & 0.0145 & 41.0913 & 0.0155 & 0.4120 & 0.7809 \\
\hline & EnvI & 0.5828 & 0.0204 & 28.5098 & 0.0223 & 0.3230 & 0.8425 \\
\hline & SocI & 0.5287 & 0.0120 & 43.9731 & 0.0145 & 0.3759 & 0.6815 \\
\hline
\end{tabular}

Table 5. Formed multiple regression models according to the vector of sustainable business model of the studied companies in the field of e-commerce.

\begin{tabular}{ccccccc}
\hline Cluster & Multiple Regression Model & $\boldsymbol{R}^{2}$ & $\boldsymbol{F}$ & $\boldsymbol{F}_{\text {crit }}$ & $\boldsymbol{t}_{\text {crit }}$ & $\boldsymbol{t}_{\text {tabl }}$ \\
\hline Cluster 1 & $S V=\begin{array}{c}\text { 0.54.EcI + 0.66.EnvI }+ \\
\text { 0.46.SocI }\end{array}$ & 0.99 & 212.99 & 9.28 & 2.36 & 25.28 \\
\hline Cluster 2 & $S V=\begin{array}{c}0.62 . \mathrm{EcI}+0.61 . \text { EnvI }+ \\
\text { 0.57.SocI }\end{array}$ & 0.98 & 1107.37 & 19.16 & 2.45 & 57.64 \\
\hline Cluster 3 & $S V=\begin{array}{c}\text { 0.58.EcI + 0.61.EnvI + } \\
\text { 0.50.SocI }\end{array}$ & 0.98 & 2735.18 & 215.71 & 2.57 & 90.58 \\
\hline Cluster 4 & $S V=\begin{array}{c}\text { 0.6.EcI + 0.58.EnvI + } \\
\text { 0.53.SocI }\end{array}$ & 0.99 & 14751.32 & 215.71 & 2.57 & 210.37 \\
\hline
\end{tabular}

Source: own development.

The generated models of equations are applicable in the real conditions of e-commerce. This is confirmed by a number of indicators. Determination coefficient $R^{2}$ is at the level of $97-99 \%$. According to the Fisher criterion, for all equations $-F>F_{c r i t}$. According to Student's $t$-test, for all equations- $t_{\text {tabl }}>t_{\text {crit }}$.

On the basis of the generated regression equations, modeling was conducted in order to determine the deviation of the business model sustainability vector from the reference vector. Thus, the level of business model sustainability was determined (Table 6). 
Table 6. Indicators of business model sustainability of e-commerce companies.

\begin{tabular}{|c|c|c|c|c|c|c|}
\hline Cluster & $\begin{array}{l}\text { E-Commerce } \\
\text { Company }\end{array}$ & EcI & EnvI & SocI & $\arccos \alpha$, Degrees & $\begin{array}{c}\text { Business Model Sustainability } \\
\text { Level }(B M S L), \%\end{array}$ \\
\hline \multirow{7}{*}{ Cluster 1} & $\begin{array}{l}\text { kolesa- } \\
\text { darom.ru }\end{array}$ & 0.201 & 0.651 & 0.492 & 22.6 & 64 \\
\hline & vkusvill.ru & 0.374 & 0.160 & 0.000 & 40.7 & 34 \\
\hline & utkonos.ru & 0.233 & 0.876 & 0.303 & 31.5 & 49 \\
\hline & re-store.ru & 0.157 & 0.637 & 0.409 & 26.0 & 58 \\
\hline & shop.mts.ru & 0.670 & 0.863 & 0.254 & 23.1 & 63 \\
\hline & komus.ru & 0.096 & 0.214 & 0.447 & 30.0 & 52 \\
\hline & sbermarket.ru & 0.028 & 0.287 & 0.227 & 31.4 & 49 \\
\hline \multirow{6}{*}{ Cluster 2} & goldapple.ru & 0.533 & 0.577 & 0.239 & 18.5 & 70 \\
\hline & exist.ru & 0.081 & 0.242 & 0.197 & 21.3 & 66 \\
\hline & goods.ru & 0.299 & 0.524 & 0.258 & 18.0 & 71 \\
\hline & hm.com & 0.238 & 0.293 & 0.489 & 17.6 & 72 \\
\hline & holodilnik.ru & 0.454 & 0.805 & 0.508 & 14.7 & 76 \\
\hline & leroymerlin.ru & 0.611 & 0.999 & 0.428 & 19.3 & 69 \\
\hline \multirow{5}{*}{ Cluster 3} & sunlight.net & 0.575 & 0.523 & 0.254 & 17.3 & 72 \\
\hline & bonprix.ru & 1.026 & 0.849 & 0.667 & 9.8 & 84 \\
\hline & vprok.ru & 0.612 & 0.415 & 0.341 & 14.1 & 77 \\
\hline & ikea.com & 0.231 & 0.362 & 0.451 & 14.6 & 76 \\
\hline & vseinstrumenti.ru & 0.419 & 0.554 & 0.583 & 7.9 & 87 \\
\hline \multirow{5}{*}{ Cluster 4} & svyaznoy.ru & 0.630 & 0.526 & 0.655 & 5.3 & 91 \\
\hline & onlinetrade.ru & 0.762 & 0.738 & 0.527 & 8.9 & 86 \\
\hline & technopoint.ru & 0.821 & 0.687 & 0.727 & 4.3 & 93 \\
\hline & sportmaster.ru & 0.654 & 0.632 & 0.727 & 3.5 & 94 \\
\hline & sima-land.ru & 0.390 & 0.499 & 0.511 & 6.6 & 89 \\
\hline
\end{tabular}

Source: own development.

Conducted modeling and determining the level of business model sustainability allow one to determine a relationship between it and the performance of companies in the field of e-commerce in the context of economic, environmental and social directions. For companies in the first cluster, which are characterized by a low value of the business model sustainability vector, there is a correspondingly low level of comprehensive business model sustainability: an average of $53 \%$. For the companies with the highest business model sustainability vector values (the fourth cluster) recorded the highest level of business sustainability: an average of $91 \%$. Thus, it is possible to confirm the acceptance of the second hypothesis, as an increase in the sustainability vector brings a company closer to the benchmark value of sustainable business.

\section{Discussion}

Compared to the results of other authors demonstrating the need to apply design thinking to sustainable innovation in business models [36], this study provides a frame for its application. However, the study does not focus on revealing all the problems associated with innovation in sustainable business models. The conducted research forms a platform for developing recommendations on implementing this frame and presents key practical points for sustainable business. That said, a study of sustainable online models has a similar result, which confirms transcendence beyond personal habits and the great potential to 
influence larger social institutions and societal habits [37]. The advantages of this study over similar works of scientists who focused on the innovation component of business models [38-40] are:

1. focus on the sustainability aspects of the e-commerce business model;

2. integration of the three components of improving its effectiveness;

3. innovation, a way to achieve a high level of sustainability, is not the prerogative or the key direction.

Compared to the results of other scholars [41], in which B2C e-commerce has three sub-models: value offering; value creation and delivery; and value capture. The formed methodological approach in this study focuses on assessing the level of business model sustainability. This study proves that achieving a high level of business model sustainability takes into account the migration of consumer values. The positive side of this study can be defined as the applicability of the proposed vector scheme to both B2B models [42] and C2C e-commerce models [43]. This demonstrates the comprehensiveness of its application.

The study proves the need to develop e-commerce companies simultaneously in different directions, because the sustainability of their business model requires the economic, environmental and social balance of efficiency [44]. The obtained study results in the context of vector deviations indicate that they are equal in the process of forming a sustainable business model. In addition, in the modern scientific literature on the given problems, there are studies that also point to the need to take into account the economic, environmental and social components of e-commerce effectiveness [45]. In this case, the achievement of a high level of sustainability is interpreted as the achievement of "trade-offs" in the process of forming a business model [46].

The proposed methodological approach allows for taking into account the versatile efficiency in each of the three areas considering sustainability efficiency as a comprehensive integral indicator. While other studies focus on individual components: the service concept of the e-commerce business model [28], reduction of resource consumption [29,30] or cooperation between companies to develop and implement new environmentally friendly technologies [26]. The formed system of indicators can be complemented by performance indicators of long-term design, maintenance, reuse, recycling and reconstruction to ensure business model sustainability $[30,31]$.

The positive side of this study is the proposed methodological approach, which integrates a variety of tools into one set of assessing the level of business model sustainability based on the indicator in the form of a vector. It should be noted that some elements of this methodological approach have been previously applied in other studies. For example, the clustering of e-commerce companies is widely used [47,48]. However, it is the environmental and social side of business efficiency that is not taken into account. Quite common are studies of business modeling of e-commerce using regression analysis and diagnosis of influencing factors on the level of e-commerce efficiency in the context of sustainable development $[49,50]$. However, these studies are conducted at the macro level and do not provide an opportunity to identify priorities for specific e-commerce companies. The most common is the use of correlation analysis to study the relationships between individual factors of e-commerce efficiency in a sustainable development environment [51,52]. In general, the study demonstrated the possibility of applying a set of methods to assess business model sustainability of a company, taking into account the characteristics of its functioning and comparing the results with the effects on other companies. Thus, it is possible to carry out competitive diagnostics of business models in the context of their sustainable development [53]. The proposed approach allows one not only to diagnose business model sustainability [26,27], but also to compare companies with each other in a competitive environment to determine the priorities of their functioning to achieve leadership positions in the context of sustainable development.

This study is limited to three indicators of the effectiveness of a sustainable business model. However, the proposed approach allows one to expand the number of reference vectors and, accordingly, the system of indicators. In addition, the limitation of the study 
is the lack of public information from companies, which is necessary for the calculations. Therefore, the breadth of the sample of companies depends on the interest of e-commerce companies in such research and their consent to provide the necessary data. The larger the sample of companies surveyed, the more accurate and comprehensive the results will be for e-commerce.

In the future, research may be aimed at expanding the proposed methodological approach in the context of the diversity of indicators of a performance assessment model for a sustainable e-commerce business model. It is possible to apply the proposed methodological approach to enterprises in other industries, taking into account the specifics of their activities. This requires the transformation of the proposed system of indicators in the context of industry peculiarities. It is also possible to expand the geographical boundaries of the study and conduct a comparative characterization of the results obtained not only between specific groups of enterprises, but also between countries or regions.

\section{Conclusions}

The scientific contribution of this study is the proposed methodological approach to assessing business model sustainability in e-commerce, which allows taking into account the economic, environmental and social components of its effectiveness. It allows one not only to diagnose business model sustainability, but also to compare companies with each other in a competitive environment, to determine the priorities of their functioning to achieve leadership positions on the background of sustainable development. The theoretical results of this study are the formed scheme of business model sustainability vector construction, which allows one to harmonize business model sustainability based on three key dimensions. The formed system of key indicators provides an opportunity to determine the integral indicators of sustainable business model. It provides an opportunity to identify the deviations of the sustainability vector of the business model and determine the priorities of the e-commerce company to improve the level of efficiency in the given areas. The integrated implementation of correlation, cluster and regression analysis allowed for forming an integrated toolkit for scenario modeling of business model sustainability for the studied companies.

Practical aspects of this study are the results of testing the proposed methodological approach on the materials of the studied companies in the field of e-commerce. The assessment of business model sustainability makes it possible to identify leaders and outsiders among the studied e-commerce companies in the context of such areas as economic, environmental and social efficiency. In this case, the proposed methodological approach allows one to take into account the versatile efficiency in each of the three areas based on determining the level of sustainability efficiency as a comprehensive integral indicator. Such an indicator in this study is the vector of business model sustainability. Imputed correlation analysis allowed for identifying the most significant indicators for e-commerce companies. The correlation analysis proved that in modern conditions not only the economic component is significant for the efficiency of the business model in e-commerce, but also the environmental component at the same level of interdependence.

Clustering of the studied e-commerce companies provided an opportunity to take into account the peculiarities of the performance of the studied companies, to group them taking into account similar performance indicators. This made it possible to develop more accurate regression models for each cluster. In this case, there is a correlation between the value of the sustainability vector of the business model of a company and its assignment to a particular cluster.

Based on regression analysis, it was determined that for the first and third clusters, the most significant is the environmental factor (impact on the external environment). For the second and fourth clusters, the most significant is the economic efficiency of e-commerce. For all clusters, the least significant is the social factor. The generated regression equations provide the possibility of modeling. This allows one to determine the deviations of the 
business model sustainability vector from the reference vector, which demonstrates the level of its effectiveness.

The conducted modeling and determination of the business model sustainability allow one to determine a relationship between it and the performance of companies in the field of e-commerce in the context of economic, environmental and social dimensions. At the same time, the obtained results demonstrate that the increase in the sustainability vector brings a company closer to the benchmark business sustainability. Thus, it is proven that for e-commerce companies in the process of business modeling, their sustainability parameters play a defining role.

This study is limited to three indicators of sustainable business model effectiveness. However, the proposed approach allows one to expand the number of reference vectors and, accordingly, the system of indicators. In addition, the limitation of this study is the lack of public information from companies, which is necessary for the calculations. Therefore, the breadth of the sample of companies depends on the loyalty of e-commerce companies, their interest in such research and their consent to provide the necessary data.

Future research may extend the proposed methodological approach in the context of varying indicators of assessing the effectiveness of a sustainable e-commerce business model. At the same time, the study can also expand the range of application of the proposed methodological approach to enterprises in other industries, taking into account the specifics of their activities. This requires the transformation of the proposed system of indicators in the context of industry peculiarities. In the future, the study can be tested by expanding the geographical boundaries and conducting a comparative characterization of the results obtained not only between specific groups of enterprises, but also between countries or regions. Prospects for further research in this direction suggest that solving problems and applying the principles of sustainable e-commerce can be the basis for the reorientation of national systems of management of e-business processes on sustainable development. However, determining the content of such regulated processes requires a mathematical assessment of the forms and vectors that define directions to minimize harm to the ability of future generations to meet their own needs and levels of conducting more responsible e-commerce business activities (mapping reorientation).

Author Contributions: Conceptualization, N.H., P.Z. and K.G.; methodology, M.S.; software, P.Z.; validation, M.S., N.H. and P.Z.; formal analysis, M.S.; investigation, N.H. and K.G.; resources, P.Z.; data curation, M.S. and K.G.; writing—original draft preparation, M.S.; writing-review and editing, N.H.; visualization, P.Z.; supervision, M.S. and K.G.; project administration, N.H.; funding acquisition, K.G. All authors have read and agreed to the published version of the manuscript.

Funding: This research received no external funding.

Institutional Review Board Statement: Not applicable.

Informed Consent Statement: Not applicable.

Data Availability Statement: Data is available upon a request.

Conflicts of Interest: The authors declare no conflict of interest.

\section{References}

1. Nielsen Report. Future Opportunities in FMCG E-Commerce. 2020. Available online: https://www.nielsen.com/ssa/en/ insights/report/2018/future-opportunities-in-fmcg-ecommerce/ (accessed on 17 September 2021).

2. Tran, L.T.T. Managing the effectiveness of e-commerce platforms in a pandemic. J. Retail. Consum. Serv. 2021, 58, 102287. [CrossRef]

3. Guo, Y.; Yin, C.; Li, M.; Ren, X.; Liu, P. Mobile e-commerce recommendation system based on multi-source information fusion for sustainable e-business. Sustainability 2018, 10, 147. [CrossRef]

4. Ingaldi, M.; Ulewicz, R. How to make e-commerce more successful by use of Kano's model to assess customer satisfaction in terms of sustainable development. Sustainability 2019, 11, 4830. [CrossRef]

5. Escursell, S.; Llorach-Massana, P.; Roncero, M.B. Sustainability in e-commerce packaging: A review. J. Clean. Prod. 2021, 280, 124314. [CrossRef] [PubMed] 
6. Chen, W.; Yan, W. Impact of internet electronic commerce on $\mathrm{SO}_{2}$ pollution: Evidence from China. Environ. Sci. Pollut. Res. 2020, 27, 25801-25812. [CrossRef] [PubMed]

7. Cárdenas, I.; Beckers, J.; Vanelslander, T. E-commerce last-mile in Belgium: Developing an external cost delivery index. Res. Transp. Bus. Manag. 2017, 24, 123-129. [CrossRef]

8. Tsindeliani, I.; Selyukov, A.; Kikavets, V.; Vershilo, T.; Tregubova, E.; Babayan, O.; Badmaev, B.; Shorin, S. Transformation of the legal mechanism of taxation as a factor of influence on strategic planning of budgetary policy: Russia case study. J. Transnatl. Manag. 2021, 26, 179-200. [CrossRef]

9. Shen, L.; Wang, X.; Liu, Q.; Wang, Y.; Lv, L.; Tang, R. Carbon trading mechanism, low-carbon e-commerce supply chain and sustainable development. Mathematics 2021, 9, 1717. [CrossRef]

10. Ptashkina, M. Facilitation 2.0: E-Commerce and trade in the digital age. RTA Exchange 2018. [CrossRef]

11. Jones, P.; Maas, G.; Dobson, S.; Newbery, R.; Agyapong, D.; Matlay, H. Entrepreneurship in Africa, Part 1: Entrepreneurial dynamics in Africa. J. Small Bus. Enterp. Dev. 2018, 25, 346-348. [CrossRef]

12. Yu, H.; Cui, L. China's e-commerce: Empowering rural women? China Q. 2019, 238, 418-437. [CrossRef]

13. Li, L.; Du, K.; Zhang, W.; Mao, J.Y. Poverty alleviation through government-led e-commerce development in rural China: An activity theory perspective. Inf. Syst. J. 2019, 29, 914-952. [CrossRef]

14. Kar, A.K. What affects usage satisfaction in mobile payments? Modelling user generated content to develop the "digital service usage satisfaction model". Inf. Syst. Front. 2021, 23, 1341-1361. [CrossRef] [PubMed]

15. Adam, M.; Ibrahim, M.; Ikramuddin, I.; Sahputra, H. The role of digital marketing platforms in supply chain management for customer satisfaction and loyalty in Small and Medium Enterprises (SMEs) in Indonesia. Int. J. Supply Chain Manag. 2020, 9 , 1210-1220.

16. Khan, H.U.; Uwemi, S. What are e-commerce possible challenges in developing countries: A case study of Nigeria. Int. J. Bus. Syst. Res. 2018, 12, 454-486. [CrossRef]

17. Wang, Y.; Jia, F.; Schoenherr, T.; Gong, Y.; Chen, L. Cross-border e-commerce firms as supply chain integrators: The management of three flows. Ind. Mark. Manag. 2020, 89, 72-88. [CrossRef]

18. Hussain, A.; Shahzad, A.; Hassan, R. Organizational and Environmental Factors with the Mediating Role of E-Commerce and SME Performance. J. Open Innov. Technol. Mark. Complex. 2020, 6, 196. [CrossRef]

19. Olsson, A.K.; Bernhard, I. Keeping up the pace of digitalization in small businesses-Women entrepreneurs' knowledge and use of social media. Int. J. Entrep. Behav. Res. 2020, 27, 378-396. [CrossRef]

20. Lu, S.; Yang, L.; Liu, W.; Jia, L. User preference for electronic commerce overpackaging solutions: Implications for cleaner production. J. Clean. Prod. 2020, 258, 120936. [CrossRef]

21. Villa, E.; Ruiz, L.; Valencia, A.; Picón, E. Electronic commerce: Factors involved in its adoption from a bibliometric analysis. J. Theor. Appl. Electron. Commer. Res. 2018, 13, 39-70. [CrossRef]

22. Chen, C.L.; Lin, Y.C.; Chen, W.H.; Chao, C.F.; Pandia, H. Role of government to enhance digital transformation in small service business. Sustainability 2021, 13, 1028. [CrossRef]

23. Cheba, K.; Kiba-Janiak, M.; Baraniecka, A.; Kołakowski, T. Impact of external factors on e-commerce market in cities and its implications on environment. Sustain. Cities Soc. 2021, 72, 103032. [CrossRef]

24. Jiang, X.; Wang, H.; Guo, X.; Gong, X. Using the FAHP, ISM, and MICMAC approaches to study the sustainability influencing factors of the last mile delivery of rural E-commerce logistics. Sustainability 2019, 11, 3937. [CrossRef]

25. Kumar, N.; Anusara, J.; Hossin, M.A.; Sarkar, M.K.; Chanthamith, B.; Shah, S.; Russel, M.I.H. Challenges and opportunities of e-commerce in India: Pathway for sustainable e-commerce. Int. J. Eng. Bus. Manag. 2018, 2, 13-21.

26. Sharma, H.; Aggarwal, A.G. Finding determinants of e-commerce success: A PLS-SEM approach. J. Adv. Manag. Res. 2019, 16, 453-471. [CrossRef]

27. Ardiansah, M.; Chariri, A.; Rahardja, S.; Udin, U. The effect of electronic payments security on e-commerce consumer perception: An extended model of technology acceptance. Manag. Sci. Lett. 2020, 10, 1473-1480. [CrossRef]

28. Jiang, Y.; Lai, P.; Chang, C.H.; Yuen, K.F.; Li, S.; Wang, X. Sustainable management for fresh food e-commerce logistics services. Sustainability 2021, 13, 3456. [CrossRef]

29. Liu, C.; Jia, G.; Kong, J. Requirement-oriented engineering characteristic identification for a sustainable product-service system: A multi-method approach. Sustainability 2020, 12, 8880. [CrossRef]

30. Meherishi, L.; Narayana, S.A.; Ranjani, K.S. Sustainable packaging for supply chain management in the circular economy: A review. J. Clean. Prod. 2019, 237, 117582. [CrossRef]

31. Trifonov, P.V.; Kirpicheva, M.A.; Khachatryan, A.A. Analysis of the Factors and Scenarios of Forming a New Direction in the 21st Century Energy-Intelligent Energy Networks (Smart Grid). In Institute of Scientific Communications Conference; Springer: Cham, Swizterland, 2019; pp. 257-264.

32. Frei, R.; Jack, L.; Krzyzaniak, S.A. Sustainable reverse supply chains and circular economy in multichannel retail returns. Bus. Strategy Environ. 2020, 29, 1925-1940. [CrossRef]

33. Aspara, J.; Grant, D.B.; Holmlund, M. Consumer involvement in supply networks: A cubic typology of C2B2C and C2B2B business models. Ind. Mark. Manag. 2021, 93, 356-369. [CrossRef]

34. Cecen, A.; Dai, H.; Yabansu, Y.C.; Kalidindi, S.R.; Song, L. Material structure-property linkages using three-dimensional convolutional neural networks. Acta Mater. 2018, 146, 76-84. [CrossRef] 
35. Radenkovic, D.; Simonin, O. Modelling of three-dimensional particle rebound from an anisotropic rough wall. Powder Technol. 2021, 393, 165-183. [CrossRef]

36. He, J.; Ortiz, J. Sustainable business modeling: The need for innovative design thinking. J. Clean. Prod. 2021, $298,126751$. [CrossRef]

37. Galea, C.; Walton, S. Is e-commerce sustainable?: Lessons from Webvan. In The Ecology of the New Economy; Routledge: London, UK, 2017; pp. 100-109.

38. Wang, Y.; Jia, F.; Schoenherr, T.; Gong, Y. Supply chain-based business model innovation: The case of a cross-border E-commerce company. Sustainability 2018, 10, 4362. [CrossRef]

39. Boichenko, K.; Shvydanenko, G.; Besarab, S.; Shvydka, O.; Kyryliuk, O. Marketing innovations management in the context of integrated enterprise development. Int. J. Manag. 2020, 11, 126-137.

40. Yun, J.J.; Zhao, X.; Park, K.; Shi, L. Sustainability condition of open innovation: Dynamic growth of alibaba from SME to large enterprise. Sustainability 2020, 12, 4379. [CrossRef]

41. Chen, J.; Guo, Z.; Tang, Y. Research on B2C E-commerce business model based on system dynamics. AJIBM 2019, 9, 854. [CrossRef]

42. Tanveer, M. Analytical approach on small and medium Pakistani businesses based on ecommerce ethics with effect on customer repurchase objectives and loyalty. J. Leg. Ethical Regul. Issues 2021, 24, 1-20.

43. Sukrat, S.; Papasratorn, B. A maturity model for C2C social commerce business model. Int. J. Electron. Commer. Stud. 2018, 9 , 27-54. [CrossRef]

44. Ignat, B.; Chankov, S. Do e-commerce customers change their preferred last-mile delivery based on its sustainability impact? Int. J. Logist. Manag. 2020, 31, 521-548. [CrossRef]

45. Dutta, P.; Mishra, A.; Khandelwal, S.; Katthawala, I. A multiobjective optimization model for sustainable reverse logistics in Indian E-commerce market. J. Clean. Prod. 2020, 249, 119348. [CrossRef]

46. Oláh, J.; Kitukutha, N.; Haddad, H.; Pakurár, M.; Máté, D.; Popp, J. Achieving sustainable e-commerce in environmental, social and economic dimensions by taking possible trade-offs. Sustainability 2019, 11, 89. [CrossRef]

47. Prajapati, D.; Harish, A.R.; Daultani, Y.; Singh, H.; Pratap, S. A clustering based routing heuristic for last-mile logistics in fresh food E-commerce. Glob. Bus. Rev. 2020, in press. [CrossRef]

48. Zeng, Y.; Guo, H.; Yao, Y.; Huang, L. The formation of agricultural e-commerce clusters: A case from China. Growth Change 2019, 50, 1356-1374. [CrossRef]

49. Tzavlopoulos, I.; Gotzamani, K.; Andronikidis, A.; Vassiliadis, C. Determining the impact of e-commerce quality on customers' perceived risk, satisfaction, value and loyalty. Int. J. Qual. Serv. Sci. 2019, 11, 576-587. [CrossRef]

50. Waseem, A.; Rashid, Y.; Warraich, M.A.; Sadiq, I.; Shaukat, Z. Factors affecting E-commerce potential of any country using multiple regression analysis. J. Internet Bank. Commer. 2019, 24, 1-28. [CrossRef]

51. Abdullah, L.; Ramli, R.; Bakodah, H.O.; Othman, M. Developing a causal relationship among factors of e-commerce: A decision making approach. J. King Saud Univ. Comput. Inf. Sci. 2020, 32, 1194-1201. [CrossRef]

52. Liu, J.; Liu, C.; Zhang, L.; Xu, Y. Research on sales information prediction system of e-commerce enterprises based on time series model. Inf. Syst. e-Bus Manag. 2020, 18, 823-836. [CrossRef]

53. Alsaad, A.; Mohamad, R.; Taamneh, A.; Ismail, N.A. What drives global B2B e-commerce usage: An analysis of the effect of the complexity of trading system and competition pressure. Technol. Anal. Strateg. Manag. 2018, 30, 980-992. [CrossRef] 